\title{
HOW PREVALENT IS TAX ARBITRAGE? EVIDENCE FROM THE MARKET FOR MUNICIPAL BONDS
}

\author{
Merle Erickson \\ Austan Goolsbee \\ Edward Maydew \\ Working Paper 9105 \\ http://www.nber.org/papers/w9105 \\ NATIONAL BUREAU OF ECONOMIC RESEARCH \\ 1050 Massachusetts Avenue \\ Cambridge, MA 02138 \\ August 2002
}

We appreciate helpful comments from John Chalmers (the discussant), Michelle Yetman, an anonymous referee, and workshop participants at Iowa, Ohio State, USC, Wharton, and the 2002 UNC Tax Symposium. Financial support was received from the American Bar Foundation, the Price Waterhouse Foundation, the KPMG Peat Marwick Research Fellowship Fund, University of Chicago and the University of North Carolina. The views expressed herein are those of the authors and not necessarily those of the National Bureau of Economic Research.

(C) 2002 by Merle Erickson, Austan Goolsbee and Edward Maydew. All rights reserved. Short sections of text, not to exceed two paragraphs, may be quoted without explicit permission provided that full credit, including $\odot$ notice, is given to the source. 
How Prevalent is Tax Arbitrage? Evidence from the Market for Municipal Bonds

Merle Erickson, Austan Goolsbee and Edward Maydew

NBER Working Paper No. 9105

August 2002

JEL No. H2

\begin{abstract}
Although tax arbitrage is central to the literatures on tax capitalization, implicit taxes, and even capital structure, there is little empirical evidence of the extent to which firms actually engage in tax arbitrage. This paper provides some evidence on the topic by focusing on a simple and observable corporate arbitrage strategy in the market for municipal bonds. It poses a puzzle for the literature, however, in that we find little evidence of municipal bond tax arbitrage by non-financial corporations. The overwhelming majority of firms are not engaging in the arbitrage at all and even among those engaged in arbitrage, many firms do less than a safe-harbor amount allowed by the tax authorities. Such a pattern is consistent with the presence of both fixed and marginal (i.e., that depend on size of the position) costs of arbitrage, though we cannot observe what those costs are.
\end{abstract}

\author{
Merle Erickson \\ University of Chicago \\ Graduate School of Business \\ Austan Goolsbee \\ University of Chicago \\ Graduate School of Business \\ 1101 E. 58th St. \\ Chicago, IL 60637 \\ and NBER \\ goolsbee@gsb.uchicago.edu \\ Edward Maydew \\ University of North Carolina \\ Kenan-Flagler Business School
}




\section{Introduction}

Tax arbitrage plays a central role in the literatures on capital structure, tax capitalization, and implicit taxes. Though it is common to assume that market participants will take advantage of any discrepancies in returns across assets caused by tax differences, this is based more on theory than on empirical evidence. Indeed, most tax arbitrageurs do their best to keep their means of operation secret. ${ }^{1}$ Actual empirical evidence of the extent to which firms engage in arbitrage is scarce and important. ${ }^{2}$

This paper provides some evidence from the market for municipal bonds. The results pose a puzzle to existing theory, however. We find that although the tax authorities effectively permit a limited amount of arbitrage that would appear to be a source of "free money" for many corporations, few firms outside the financial sector actually engage in it. In addition, we also document that even among those engaging in arbitrage, many firms are doing less than a safe-harbor amount allowed by law. To explain these facts, there must be costs of arbitrage that are marginal in the sense that they rise with the size of the position, not just fixed costs as typically assumed.

The existence of such arbitrage costs may help explain why tax-induced pricing effects in the municipal bond market tend to be smaller than commonly predicted and, more broadly, why the effects of investor level taxes on asset prices have been more modest than some theories would predict. Our empirical analysis, though focused on tax

\footnotetext{
${ }^{1}$ The suppliers of such services have in the past typically required their clients to sign non-disclosure agreements. There are good reasons for them to keep such strategies quiet, both to prevent duplication by other firms since the government does not provide much intellectual property protection for tax planning strategies (Bankman 1998) and to prevent increased IRS scrutiny. For example, there is evidence that the IRS pays attention to firm's book-tax differences as an audit tool (Guenther, Nutter, and Maydew, 1997; Mills, 1998).

${ }^{2}$ For evidence in other circumstances see, for example, Altshuler and Gentry (1996), Cummins and Grace (1994), or Gentry (forthcoming).
} 
arbitrage, is in the spirit of work by Shleifer and Vishny (1998) who show how agency and liquidity problems can create impediments to financial arbitrage.

We focus on documenting a very simple type of tax arbitrage-borrowing to invest in tax-exempt municipal bonds-for two reasons. First, it is a type of arbitrage that is directly observable in many firms' financial reports. Second, this type of arbitrage should be well-known to firms and is easy to understand and simple-involving no cross-country differences in tax rates nor complex derivatives.

We begin by examining both theoretical and practical aspects of tax arbitrage in general, and municipal bond tax arbitrage in particular. ${ }^{3}$ Our examination lays out some potential costs of municipal bond tax arbitrage, specifically tax code restrictions and nontax costs (e.g, risk differences). We then attempt to identify firms engaging in municipal bond tax arbitrage and the magnitude of their positions.

For the set of firms engaging in arbitrage, we estimate the actual arbitrage profits earned across the range of possible tax code restrictions. We use the estimated actual arbitrage activity to get a sense of the implied size of the barriers and costs of arbitrage for the majority of firms that do not engage in arbitrage. Importantly for understanding what the costs of arbitrage must be, even among the small minority of firms that do engage in this arbitrage, many firms have arbitrage positions that are modest relative to the safe-harbor level permitted by the tax authorities.

This finding is important, more generally, because if the costs of tax arbitrage in other markets may also be sufficiently high to prevent widespread arbitrage activity. This could help to explain the fact that several recent studies have found that prices only

\footnotetext{
${ }^{3}$ We use the term "municipal bond" as short-hand for all tax-exempt state and local bonds.
} 
partially reflect the effects of tax differences and that there are only small implicit tax effects in various asset markets. ${ }^{4}$

The results also have some bearing on the muni-bond puzzle (i.e., that the yield on municipal bonds is far above that implied by the after-tax rate on similar taxable bonds). The small spread between municipal and taxable bonds implies a low implicit tax rate but this contradicts most explanations of the municipal bond market by leaving significant tax arbitrage opportunities unexploited (see Chalmers, 1998 for an overview of the literature). The existence of arbitrage costs may be one component of the explanation.

The paper proceeds as follows. In the next section we discuss the prior literature on tax arbitrage, paying particular attention to the municipal bond puzzle. We discuss the tax law restrictions on municipal bond tax arbitrage in section 3 . In section 4 we identify firms engaging in tax arbitrage and provide evidence on the prevalence of tax arbitrage. In section 5 we consider reasons why municipal bond arbitrage appears to be so rare among non-financial firms. Section 6 concludes.

\section{Municipal Bond Tax Arbitrage}

The simple arbitrage strategy that is the focus of this paper is borrowing money to invest in tax-exempt municipal bonds. Such a strategy is profitable whenever the taxexempt return exceeds the after-tax cost of borrowing and this is likely to be true for many firms. For example, with AAA municipal bond yields around $4.72 \%$ and AAA

\footnotetext{
${ }^{4}$ For example, Engel, Erickson and Maydew (1999), Graham (2000), and Khanna and McConnell (1998) find evidence, using different approaches, that the tax benefits to leverage are close to their maximum possible value of $\tau \mathrm{D}$ (where $\tau$ is the corporate tax rate and $\mathrm{D}$ is the face value of debt issued) contrary to the theory of Miller (1977) which argues that there is should be no tax benefit to leverage. Papers directly examining the effects of tax difference on asset prices that find evidence of relatively small implicit tax
} 
corporate bonds yielding $5.43 \%$ (taken from the 7/12/02 Yahoo finance composite bond

rates for 20 year securities), a corporation taxed at the maximum rate has an arbitrage

opportunity of $1.19 \%$ (i.e., $4.72 \%-5.43 \%(1-.35)$ ) per dollar of arbitrage (with no

transactions costs and legal restrictions). ${ }^{5}$

The potential of this arbitrage strategy is well known. The tax law has long allowed banks to hold municipal bonds tax-free while simultaneously borrowing and deducting the interest expenses from their taxable income and banks actively engage in such arbitrage. ${ }^{6}$ Indeed, Fama (1977) argues that the possibility of arbitrage should make commercial banks the marginal investors in municipal bonds thereby equating the implied tax rate to the top marginal corporate tax rate. ${ }^{7}$ Because the Tax Reform Act of 1986 reduced banks' ability to engage in municipal bond arbitrage, many researchers feel the Fama point is now moot. ${ }^{8}$ In this paper, however, we document that, in fact, the tax law effects include Shackelford (1991), Guenther (1994), Fama and French (1998) and Erickson and Maydew (1998).

${ }^{5}$ The potential arbitrage profit is a function of the maturity of the underlying bonds. The spread on shorter bonds is smaller but frequently still exists. For the shortest bonds listed at Yahoo finance ( 2 year bonds), the rate on AAA municipals was 2.60 percent while the rate on AA corporate bonds (Yahoo gives no AAA corporate 2 year rate) was 2.99 percent, giving a spread of $0.66 \%$ per dollar of arbitrage. Likewise, the spread falls the higher the rate at which the corporation can borrow but the spread still exists for rates on $\mathrm{AA}, \mathrm{A}$, and $\mathrm{BB}+$ bond rates. We are not be able to observe the actual maturities of the municipal bonds held by firms in our sample since firms generally do not disclose such information. We were able to find some information about maturities at our largest municipal bondholder. They disclosed that 40 percent of their bonds had maturities greater than five years. We were unable to find references to maturities in several of the other major bond holders in our sample.

${ }^{6}$ Beek (1982), Skelton (1983), Poterba (1986), Scholes, Wolfson, and Wilson (1990), and Collins, Shackelford, and Wahlen (1995) present the evidence.

${ }^{7}$ Miller (1977) makes a different arbitrage argument that yields the same conclusion as Fama's when he argues that in a market with tax-exempt bonds, taxable corporate bonds, and equity, no matter what the demand curve by investors for tax-free bonds is, the supply of municipal bonds will be perfectly elastic at the point where the implicit tax is the corporate rate because common stocks and municipal bonds are perfect substitutes in an investor's portfolio and the effective tax on equity is close to zero (so they must have the same returns in equilibrium).

${ }^{8} \mathrm{~A}$ voluminous empirical literature has examined these theories and calculated the implicit marginal tax rates for municipal bond holders and how they respond to economic factors. See, for example, Skelton, (1983), Trczinka (1982), Poterba (1986), Buser and Hess (1986), Kochin and Parks (1988), Poterba (1989), Gordon and Metcalf (1991), Greinel and Slemrod (1998), and Chalmers (1998). The recent evidence has not supported the arbitrage views of Fama/Miller. Most implied tax rates are below corporate rates and the 
still allows non-financial corporations to engage in a limited amount of the exactly the same arbitrage that banks have used (this provision is noted in Scholes and Wolfson, 1992 and Chalmers, 1998). So long as the firm's interest rate is not too high, this ought to create the same arbitrage condition that the implicit tax rate should equal the corporate rate. Firms are allowed to borrow (through debt) and lend (through tax-free municipal bonds) at different rates and thus are a natural candidate to be the marginal investor.

Note that we are adopting a strict view of what defines arbitrage (holding debt and muni-bonds simultaneously). A more lenient view of arbitrage might be that any type of borrowing (say, leasing equipment rather than buying it) coupled with holdings of municipal bonds is like tax arbitrage. Accordingly, we will present evidence using the traditional view of arbitrage as well as evidence of the complete holding of municipal bonds.

\section{Tax Law Restrictions on Municipal Bond Tax Arbitrage}

In an effort to prevent wholesale arbitrage, the IRS does place some specific restrictions on municipal bond tax arbitrage that we consider here. Municipal bond tax arbitrage is restricted though the disallowance of deductions for interest on debt that is used to finance assets that produce tax-exempt income. At first glance, this would appear to make corporate municipal bond tax arbitrage impossible. The interest disallowance rules, contained in I.R.C. $\S 265$ (Section 265), are more complicated than they first appear, however. First, one must evaluate whether there is tax arbitrage by the legal (as

yield spreads respond to current and expected changes to individual tax rates. 
opposed to the economic) definition. Second, if so, the firm is subject to interest

disallowance rules.

The IRS does not define tax arbitrage in an economic way, however. They do not follow the principle of fungibility of cash. If a firm holding municipal bonds has any debt, it could reduce its borrowings by reducing its municipal bond investment. From an economic point of view it does not matter whether the proceeds from a particular loan were the dollars actually used to purchase the municipal bonds and it does not matter whether the borrowing and investing is initiated simultaneously. To the IRS, however, whether the tax law considers debt as being used to finance assets that produce tax exempt income depends on the "facts and circumstances" involved. ${ }^{9}$

The main guidance from the IRS on this subject is found in Rev. Proc. $72-18{ }^{10}$ For interest disallowance to occur under these rules, there must be "a determination, based on all the facts and circumstances, as to the taxpayer's purpose in incurring or continuing each item of indebtedness. Such purpose may, however, be established by either direct or circumstantial evidence....Direct evidence of a purpose to purchase tax-exempt obligations exists where the proceeds of indebtedness are used for, and are directly traceable to, the purchase of tax-exempt obligations...Direct evidence of a purpose to carry tax-exempt obligations exists where tax-exempt obligations are used as collateral

\footnotetext{
${ }^{9}$ In contrast, developing bright-line tests can sometimes backfire on the tax authorities, as illustrated in Erickson and Wang's (1999) analysis of the DuPont/Seagram transaction.

${ }^{10}$ As mentioned before, prior to the mid 1980s, banks enjoyed special provisions allowing them to deduct the interest on debt issued to purchase or carry tax-exempt securities, causing banks to own large amounts of municipal bonds during this period. This provision applies to banks and other financial institutions that accept deposits from the public in the ordinary course of business. Over the 1980s, however, Congress gradually reduced this special provision, finally eliminating it with the Tax Reform Act of 1986. In Rev. Rul. 90-44, the IRS laid out the methodology for determining the portion of the bank's interest expense that is allocable to tax-exempt securities. We will exclude financial firms from our sample so as to avoid these more complicated issues.
} 
for indebtedness." We will call this direct tracing. Presumably, if a firm documented its intention to borrow and invest simultaneously as being a tax avoidance strategy, this would also constitute direct tracing. If specific debt can be directly traced to the municipal bonds, all of the interest on that particular debt is disallowed. Firms whose managers understand fungibility are likely to be able to avoid direct tracing.

In the absence of direct evidence that indebtedness was used to purchase or carry taxexempt securities, Rev. Proc 72-18 states that Sec. 265 will apply only if "the totality of facts and circumstances supports a reasonable inference that the purpose to purchase or carry tax-exempt obligations exists." We call this indirect tracing. ${ }^{11}$ The courts have looked to several factors to determine whether to disallow interest under indirect tracing. For example, if the loans are supported by collateral other than tax-exempt securities then the interest deductions are allowed. ${ }^{12}$ Indirect tracing results in the disallowance of a portion of the firm's interest deductions based on the ratio of municipal bonds to total assets. $^{13}$

\footnotetext{
${ }^{11}$ Personal tax arbitrage is also possible in the same way. Rev. Proc. 72-18 generally exempts home mortgage interest from these rules, stating that interest disallowance will not apply "to an individual who holds salable municipal bonds and takes out a mortgage to buy a residence instead of selling his municipal bonds to finance the purchase price. Under such circumstances the purpose of incurring the indebtedness is so directly related to the purpose of acquiring a residence that no sufficiently direct relationship between the borrowing and the investment in tax-exempt obligations may reasonably be inferred." Loans taken out to make improvements are also exempted (see Altshuler and Gentry (1996) for discussion of personal arbitrage).

12 E.L. Levitt, CA-8, 75-11 USTC Para. 9508, 517 F2d 1339. Other factors that support deductibility include: 1) whether the loan is used to finance major, nonrecurring long-ran business opportunities, 2) whether business reasons are the sole motivation for incurring the debt, 3) whether no reasonable person would sacrifice the liquidity and security of the firm's portfolio by selling the tax-exempt securities (Kramer 1991). On the other hand, disallowance is likely if the firm can reasonably foresee at the time of purchasing tax-exempt securities that a loan is probably needed to meet future economic needs of an ordinary, recurrent variety (Wisconsin Cheeseman, Inc. CA-7, 68-1 USTC Para. 9145, 388 F2d 420). In essence the rules for indirect tracing only partially embrace the notion of fungibility.

${ }^{13}$ This formula was adopted by the courts in the 1969 J.E. Leslie case and by the IRS in Rev. Proc. 72-18.
} 
There is, however, a de minimis rule that represents a significant safe harbor.

Rev. Proc. $72-18$ allows a firm to hold municipal bonds in an amount equal to 2 percent of its assets without running afoul of indirect tracing (the direct tracing rules still apply). Furthermore, exceeding the 2 percent de minimis threshold does not automatically trigger indirect tracing. In general, the 2 percent de minimis applies to both corporations and individuals, but does not apply to dealers in municipal bonds.

Note, however, that 2 percent of all corporate assets is a very large number and should permit corporations to be major players in the municipal bond market. The value in the corporate sector of equipment and structures alone (i.e., leaving out all other assets) is estimated by the B.E.A. at almost $\$ 6.5$ trillion in 1996. In theory, firms could then hold at least $\$ 130$ billion of municipal bonds strictly for tax arbitrage.

\section{Finding Firms Engaging in Tax Arbitrage}

\section{A. Text-Based Search}

Our first set of results provide evidence of the prevalence of municipal bond arbitrage among non-financial corporations. Panel A of table 1 details the method used to identify firms engaging in municipal bond arbitrage. Firms mainly report municipal bond holdings in two places in their annual reports: 1) a footnote listing the type, cost and fair market value of the marketable securities it owns at year-end, and 2) the reconciliation of the firm's effective tax rate to the statutory rate, which reports if the firm has earned taxexempt income. Some firms report municipal bonds in both places, some in only one. The general results are reported in Table 1, panel A. Of the 11,057 U.S. firms on the July 1997 Compact Disclosure database (generally containing 1996 data) that are 
incorporated in the United States, only 480 firms mention municipal bonds (or similar variations) in their footnotes and only 335 of these are non-financial corporations. Of the 335 , only 215 report owning any municipal bonds (the others' financial statements mention municipal bonds in some other context). ${ }^{14}$ So even using this most broad definition of tax arbitrage (i.e., merely owning municipal bonds) it is clear that only a tiny fraction of firms are engaged in it, well fewer than would be predicted from the distribution of tax rates and interest rates.

Looking at the holdings in more detail, more than 100 of the firms do not hold enough municipal bonds to report them separately. Of the 112 that do report municipal bond holdings, only 75 also have outstanding debt (meaning 37 firms are not engaging in arbitrage under our stricter definition). Of those 75 with debt, more than one quarter have municipal bond holdings less than the safe harbor level of 2 percent of their total assets. This is likely to be an underestimate of the share with small holdings since the 103 firms that do not report their municipal bond holdings are likely to have holdings too small to warrant separate disclosure. Regardless of how we analyze the data, it is quite clear from he key word search analysis that a tiny fraction of companies seem to be engaged in any significant amount of arbitrage.

In panel $\mathrm{A}$ of table 2, we present more detailed financial characteristics of the 75 arbitraging firms. The first two columns describe the group as a whole. The adjacent columns split the group between those with municipal bond positions less than and greater than 2 percent of assets. As the table indicates, the average (median) sample firm

\footnotetext{
${ }^{14}$ Comparing these counts to those of earlier years, it seems that SFAS 115 (accounting for marketable securities), which was effective for years ending after December 15, 1994, significantly increased firm disclosures.
} 
has total assets of $\$ 1.52$ billion ( $\$ 197.9$ million) and average (median) municipal bond holdings of $\$ 47.5$ million ( $\$ 14.9$ million). This is only about 3 percent of assets in the aggregate. Smaller firms tend to have larger positions as a share of their assets so the unweighted average and median municipal bond to asset ratio in the sample is higher than 3 percent.

The average tax arbitrage position, which we define as the minimum of municipal bonds and outstanding debt, is $\$ 30.4$ million but the median is only $\$ 3.5$ million. The arbitrage positions tend to be significantly smaller than the total municipal holdings (according to the strict arbitrage definition of the smaller of debt and municipal holdings). When broken out by size of municipal holdings, the more aggressive arbitrageurs tend to be smaller than the other firms, with mean total assets of $\$ 920$ million versus $\$ 3.29$ billion.

\section{B. The Largest Firms}

Given the tiny amounts of arbitrage documented in the text-based search approach, we conducted a completely different type of analysis to determine whether we were missing some of the important municipal bond holdings among corporations. This is certainly possible. For example, if a firm refers to their municipal bonds using an unusual terminology, we might miss it.

With our alternative procedure, we chose all non-financial firms with assets greater than $\$ 5$ billion in the Compact Disclosure data as of January 1999. Panel B of table 1 presents this information in tabular form. There were 571 such firms, 359 in nonfinancial services industries. We then looked in detail at the complete financial statements 
of each of these 359 firms. Their combined assets were more than $\$ 6.1$ trillion. ${ }^{15}$ Of these 359 firms, only 32 report owning municipal bonds and only 23 have sufficient holdings to report the actual amounts. Twenty of these 23 firms have debt and 60 percent of these 20 firms have municipal holdings smaller than the safe harbor amount.

We break out the detailed financial characteristics of these firms in panel B of table 2. The total municipal bond holdings of these 359 firms is about $\$ 17.4$ billion. This comprises only 0.2 percent of total assets of the non-financial corporate sector. Even among the 20 large firms engaging in arbitrage, such securities make up only 2.5 percent of their total assets of $\$ 513$ billion. Obviously these are much larger firms, by selection, but the size of the arbitrage positions still look relatively small compared to assets and the big arbitrageurs again are substantially smaller firms than the small arbitrageurs are in terms of total assets. These results corroborate the scarcity of tax arbitrage we documented in the key-word search approach. Although a somewhat higher fraction of the firms here engage in arbitrage than did in the previous sample, they are both quite small.

It does not much matter which definition of arbitrage we use, either. In the first column of table 3 we compute the estimated arbitrage profits for the firms using both samples and both the strict and the loose definition of arbitrage. ${ }^{16}$ In the two samples, the

\footnotetext{
${ }^{15}$ We classify General Electric and General Motors as financial firms because both firms have large financial services subsidiaries (GECS and GMAC) that account for nearly all of their municipal bond holdings.

${ }^{16}$ We define the size of the arbitrage position as the minimum of the firm's holdings of municipal bonds and the firm's outstanding debt. For the 1996 sample the rates are measured at December with the municipal rate (5.6 percent) from the Standard and Poors Municipal Bond Yield Index and the corporate rate (6.88 percent) from the Standard and Poors AAA Industrials Index. For the 1999 sample the rates are measured at December with the municipal rate (5.95 percent) from the 20 year bond index from Bondbuyer and the corporate rate ( 7.55 percent) from Moody's seasoned AAA corporate bonds. We checked the accuracy of our assumption of marginal rates equal to .35 for all the firms by getting the marginal tax rates estimated in
} 
loose definition, of course, generates more profits than the strict definition but, again, as a share of assets, both numbers are relatively modest. The mean profits from arbitrage in the text-based sample are about \$0.3-0.5 million per year depending on the definition of arbitrage. For the large-firm sample, where total assets are much bigger, mean profits were between $\$ 3$ and $\$ 8$ million per year. The median arbitrage profits are considerably smaller. This is just one way of saying that with an arbitrage spread of around 1 percent, it takes a large position to make significant amounts of money.

\section{Aggregate Data}

Both of our micro samples find very little in the way of tax arbitrage. Our final test of whether we are missing some other large holdings of municipal bonds comes from the Federal Reserve Board's Flow of Funds data (Federal Reserve, 2002). They present general balance sheet information on the entire non-financial, non-farm corporate sector. The data show that in 1999, total holdings of municipal securities was only $\$ 25$ billion whereas total assets was almost $\$ 16.7$ trillion. Municipal bonds are only 0.15 percent of assets for the entire sector. This is even smaller than the share we found for our large firms. Indeed, our 20 large arbitrageurs account for almost one-half of the aggregate municipal holdings for the entire non-financial, non-farm corporate sector (the largest 23 municipal bond holders accounts for close to 70 percent). To put the aggregate totals in perspective, if firms simply expanded to the safe harbor level of 2 percent of assets, total municipal bond holdings in the non-financial corporate sector would be $\$ 334$ billion, almost twenty times greater than their actual holdings. From every angle, the text-based 
sample, the sample of large firms, and the Federal Reserve data, we find little evidence of arbitrage.

\section{So Why Don't More Firms Arbitrage?}

Given the evidence that so few firms engage in tax arbitrage even in this simple setting, there must be some kinds of transactions costs (broadly defined) that prevent it. We will not be able to present evidence of which costs actually are important but we can say that some of the most commonly alleged are unlikely to be the main culprits. Fear of

IRS detection, for example, is unlikely to fully explain the puzzle. We have outlined how the penalties accrue on a firm engaged in municipal bond arbitrage. Unless the firm does a very bad job of tax planning, they will not be subject to the direct tracing penalties. Column 2 of table 3 shows, however, that for both definitions of arbitrage and in both samples, the average firm is still making a profit from the arbitrage, even after they have part of their interest disallowed. It is really only in the case of direct tracing, listed in the third column, that the profits turn into losses and direct tracing is easy to avoid.

Similarly, a traditional fixed cost of making an arbitrage transaction is unlikely to explain the data since many firms in table 2 have low absolute profits from arbitrage but still engage in it. The presence of fixed costs would prevent such small deals from taking places.

Whatever the costs of arbitrage may be, they must be at least partly marginal costs in the following sense: There may be costs that raise the costs of borrowing for the firm above the rates we have documented in this paper. Higher rates could eliminate the spread and make it unprofitable to engage in arbitrage. This might be termed a flow fixed 
cost—it affects the firm by the same proportion, no matter how large the arbitrage position is. These flow fixed costs can explain why so few firms do so but they cannot explain why, among the firms who are engaged in arbitrage, such a large fraction do less than the safe harbor level. To explain that, there must be marginal costs that rise with the size of the position.

The kinds of costs that would qualify as flow fixed costs would be things like loan origination fees for increasing debt, transactions costs/bid-ask spreads in the municipal bond market (Zuckerman (1998) claims these to be as much as 1-2 percent), the perceived risk of a future tax law change, or the perceived risk of a future change in a firm's tax status making the spread temporarily unprofitable. If these are prevalent and equivalent to something like 100 basis points (the approximate amount of the spread), they could explain why many firms do not arbitrage. None of these costs will explain why so many firms do less than the two percent level, though.

As for marginal costs—costs that rise more than proportionally with the size of the position-the list of potential culprits is much more tenuous. If IRS detection were a positive function of the position size, this would work save for the fact that the IRS penalties seem much too low to explain the behavior. If increasing leverage (but leaving net worth unchanged) raises the costs of borrowing, this could also explain it. The only other explanation we could produce was the amorphous one that the greater the share of assets a firm invests in tax arbitrage the worse a signal it may send to investors about future prospects of the firm. 


\section{Conclusions}

This paper documents the fact that very few firms are engaging in basic municipal bond tax arbitrage. Despite a significant spread between interest rates for much of the corporate sector, we find that only a tiny fraction of firms exploit such discrepancies and even among those that do, many do so at a level smaller than the legal safe-harbor. For tax arbitrage to be this rare, there must be serious transactions costs (broadly defined) associated with the activity. If true for such a simple type of tax arbitrage as this, it may be even more true for more complex types of tax arbitrage. If arbitrage is difficult and costly, this will have important implications for work on implicit taxes, tax capitalization, incidence and the role of tax policy in financial markets. Identifying the precise sources of transactions costs should, therefore, remain an important goal of future tax work. 


\section{References}

Altshuler, Roseanne and William Gentry, "Tax Arbitrage, the Choice of Tax Base and the Prospects for Tax Reform," Proceedings of the 88th Annual Conference of the National Tax Association-1995, 1996, 236-241.

Bankman, J., 1999. The new market in corporate tax shelters, Tax Notes, June 29.

Beek, D., 1982. Rethinking tax-exempt financing for state and local governments, Federal Reserve Bank of New York Quarterly Review 7, 30-40.

Buser S. and P. Hess, 1986. Empirical determinants of the relative yields on taxable and tax-exempt securities, Journal of Financial Economics 17, 335-55.

Chalmers J., 1998. Default risk cannot explain the muni puzzle: evidence from municipal bonds that are secured by U.S. Treasury Obligations, Review of Financial Studies $11,381-308$.

Collins, J., D. Shackelford, and J. Wahlen, 1995. Bank differences in the coordination of regulatory capital, earnings, and taxes. Journal of Accounting Research 33, 263292.

Cummins, David and Elizabeth Grace, "Tax Management and Investment Strategies of Property-Liability Insurers," Journal of Banking and Finance, 18, 1994, 43-72

Engel, E., M. Erickson and E. Maydew, 1999. Debt-equity hybrid securities, Journal of Accounting Research, 37, 249-274.

Erickson, M., and E. Maydew, 1998. Implicit taxes in high dividend yield stocks, The Accounting Review, 435-458.

Erickson, M. and S. Wang, 1999. Exploiting and sharing tax benefits: Seagram and DuPont, Journal of the American Taxation Association, 21.

Fama, E., 1977. A pricing model for the municipal bond market, University of Chicago working paper.

Fama E. and K. French, 1998. Taxes, financing decisions, and firm value. Journal of Finance 53, 819-844.

Federal Reserve Bank of the United States, Flow of Funds, July 2002.

Fortune, P, 1996. Do municipal bond yields forecast tax policy? New England Economic Review; 29 - 48.

Gentry, William M., "Debt, Investment, and Endowment Accumulation: The Case of Not-for-Profit Hospitals," forthcoming, Journal of Health Economics

Gordon, Roger and Gilbert Metcalf, "Do Tax-Exempt Bonds Really Subsidize Municipal Capital," National Tax Journal, December 1991.

Graham, J., 1996. Proxies for the corporate marginal tax rate. Journal of Financial Economics 42, 187-221.

Graham, J., 2000. How big are the tax benefits of debt?" Journal of Finance 55, 19011941.

Guenther, D., 1994. The relation between tax rates and pretax returns: direct evidence from the 1981 and 1986 tax rate reductions." Journal of Accounting and Economics $18,379-394$.

Guenther, D., S. Nutter and E. Maydew, 1997. Financial reporting, tax costs and book-tax conformity, Journal of Accounting and Economics 23, 225-248. 
Greimel T. and J. Slemrod, 1998. Did Steve Forbes scare the municipal bond market? NBER working paper.

Kaplan, S., 1989. Management buyouts: evidence on taxes as a source of value.” Journal of Finance, 611-632.

Khanna, A. and J. McConnell, 1998. MIPs, QuiPs and TOPrs: old wine in new bottles, Journal of Applied Corporate Finance 11, 39-44.

Kochin L. and R. Parks, 1988. Was the tax-exempt bond market inefficient or were future expected tax rates negative? Journal of Finance 43, 913-31.

Kramer, A. 1991. Financial products: taxation, regulation and design, Vol 2. John Wiley and Sons, Inc. New York, NY.

Miller, M., 1977. Debt and taxes. Journal of Finance 22, 261-275.

Mills, L., 1998. Book-tax differences and internal revenue service audit adjustments. Journal of Accounting Research, 343-356.

Poterba, J.,1986. Explaining the yield spread between taxable and tax exempt bonds." in

H. Rosen, ed., Studies in State and Local Public Finance. Chicago: University of Chicago Press, 5-48.

Poterba, J., 1989. Tax reform and the market for tax-exempt debt, $\underline{\text { Regional Science and }}$ Urban Economics 19, 537-562.

Schleifer and Vishny, 1998. The limits of arbitrage, Journal of Finance 52, 35-56.

Scholes, M., G. Wilson and M. Wolfson., 1990. Tax planning, regulatory capital planning, and financial reporting strategy for commercial banks. Review of Financial Studies 3 (4): 625-650.

Scholes, M., and M. Wolfson, 1992. Taxes and Business Strategy. Englewood Cliffs, N.J.: Prentice Hall.

Shackelford, D., 1991. The market for tax benefits: evidence from leveraged ESOPs." Journal of Accounting and Economics 14, 117-146.

Shevlin, T., 1990. Estimating corporate marginal tax rates with asymmetric tax treatment of gains and losses. Journal of the American Taxation Association 12, 51-67.

Skelton, J., 1983. Banks, firms and the relative pricing of tax-exempt and taxable bonds, Journal of Financial Economics 12, 343-55.

Trczinka, C., 1982, The pricing of tax-exempt bonds and the Miller Hypothesis, Journal of Finance 37, 907-923.

Zukerman, G. 1998. Mysterious bond pricing will get some scrutiny, The Wall Street Journal, A1. 
TABLE 1

SAMPLE OF FIRMS ENGAGING IN MUNICIPAL BOND ARBITRAGE

Panel A: Keyword Search of Compact Disclosure

Firms on Compact Disclosure (as of July 1997) ${ }^{(1)} \quad 11,772$

$\begin{array}{ll}\text { Firms incorporated in the United States } & 11,057\end{array}$

Firms that mention municipal bonds in footnotes ${ }^{(2)} \quad 480$

Firms that are not in the financial services industry $\quad 335$

$\begin{array}{ll}\text { Firms that indicate owning municipal bonds } & 215\end{array}$

Firms that disclose the amount of municipal bonds owned 112

Firms that also have outstanding debt $\quad 75$

Firms with municipal bonds less than $2 \%$ of assets $\quad 19$

Firms with municipal bonds greater than $2 \%$ of assets $\quad 56$

75

Panel B: Large Firms

Firms with over $\$ 5$ billion in assets (on Compact Disclosure January 1999) ${ }^{(3)} 571$

Firms that are not in the financial services industry 359

Firms that indicate owning municipal bonds 32

Firms that disclose the amount of municipal bonds owned 23

Firms that also have outstanding debt $\quad 20$

Firms with municipal bonds less than 2\% of assets 12

Firms with municipal bonds greater than $2 \%$ of assets $\quad 8$

Notes:

(1) This includes firms mentioning "municipal bonds," "state bonds," "tax-exempt bonds," or derivations of these terms.

(2) Source: July 1997 Compact Disclosure Database. This generally contains 1996 data.

(3) Source: January 2001 Compact Disclosure Database. This generally contains 1999 data. 
TABLE 2

DESCRIPTIVE STATISTICS FOR SAMPLE FIRMS ENGAGING IN MUNICIPAL BOND ARBITRAGE

Panel A: 75 Firms Identified Through a Keyword Search of Compact Disclosure

\begin{tabular}{|c|c|c|c|c|c|c|}
\hline \multirow[b]{2}{*}{ Variable (1) } & \multicolumn{2}{|c|}{$\begin{array}{l}\text { All } 75 \text { firms reporting } \\
\text { both muni bonds and debt }\end{array}$} & \multicolumn{2}{|c|}{$\begin{array}{l}19 \text { Firms with municipal } \\
\text { bonds }<2 \% \text { of assets ( } 2 \text { ) }\end{array}$} & \multicolumn{2}{|c|}{$\begin{array}{l}56 \text { Firms with municipal } \\
\text { bonds }>2 \% \text { of assets ( } 3 \text { ) }\end{array}$} \\
\hline & Mean & Median & Mean & Median & Mean & Median \\
\hline Assets & $\$ 1,520.5$ & $\$ 197.9$ & $\$ 3,289.8$ & $\$ 223.2$ & $\$ 920.2$ & $\$ 188.0$ \\
\hline Municipal bonds (M) & 47.5 & 14.9 & 26.4 & 1.0 & 54.6 & 17.9 \\
\hline Debt (L) & 495.8 & 5.9 & $1,178.6$ & 27.9 & 264.1 & 4.0 \\
\hline Arbitrage position & 30.4 & 3.5 & 26.4 & 1.0 & 31.8 & 3.8 \\
\hline Market value of equity & $1,214.3$ & 398.1 & $2,090.8$ & 398.1 & 881.3 & 379.8 \\
\hline Municipal bonds / assets & $11.0 \%$ & $5.2 \%$ & $0.7 \%$ & $0.5 \%$ & $14.5 \%$ & $9.8 \%$ \\
\hline Leverage (Debt / assets) & $12.6 \%$ & $4.2 \%$ & $17.8 \%$ & $12.3 \%$ & $10.9 \%$ & $2.4 \%$ \\
\hline Arbitrage position / assets & $3.9 \%$ & $1.5 \%$ & $0.7 \%$ & $0.5 \%$ & $5.0 \%$ & $2.3 \%$ \\
\hline Return on equity & $13.5 \%$ & $12.4 \%$ & $11.9 \%$ & $11.2 \%$ & $14.1 \%$ & $12.9 \%$ \\
\hline
\end{tabular}

Panel B: 20 Firms with Assets in Excess of \$5 Billion Engaging in Municipal Bond Arbitrage

\begin{tabular}{|c|c|c|c|c|c|c|}
\hline \multirow[b]{2}{*}{ Variable (1) } & \multicolumn{2}{|c|}{$\begin{array}{l}\text { All } 20 \text { firms reporting } \\
\text { both muni bonds and debt }\end{array}$} & \multicolumn{2}{|c|}{$\begin{array}{l}12 \text { Firms with municipal } \\
\text { bonds }<2 \% \text { of assets (2) }\end{array}$} & \multicolumn{2}{|c|}{$\begin{array}{l}8 \text { Firms with municipal } \\
\text { bonds }>2 \% \text { of assets (3) }\end{array}$} \\
\hline & Mean & Median & Mean & Median & Mean & Median \\
\hline Assets & $\$ 25,629.0$ & $\$ 9,718.9$ & $\$ 35,560.4$ & $\$ 9,718.9$ & $\$ 10,732.0$ & $\$ 9,702.0$ \\
\hline Municipal bonds (M) & 632.3 & 247.5 & 139.9 & 65.0 & $1,370.9$ & 646.0 \\
\hline Debt (L) & $3,170.5$ & $1,649.1$ & $4,432.9$ & $2,341.4$ & $1,276.8$ & 546.2 \\
\hline Arbitrage position & 283.2 & 131.6 & 139.9 & 65.0 & 498.2 & 335.3 \\
\hline Market value of equity & $17,230.1$ & $8,210.0$ & $10,330.9$ & $5,937.1$ & $27,578.9$ & $22,561.6$ \\
\hline Municipal bonds / assets & $5.5 \%$ & $1.5 \%$ & $0.7 \%$ & $0.7 \%$ & $12.6 \%$ & $5.6 \%$ \\
\hline Leverage (Debt / assets) & $17.1 \%$ & $13.6 \%$ & $22.2 \%$ & $20.9 \%$ & $9.4 \%$ & $7.6 \%$ \\
\hline Arbitrage position / assets & $2.1 \%$ & $1.0 \%$ & $0.7 \%$ & $0.7 \%$ & $4.2 \%$ & $3.6 \%$ \\
\hline Return on equity & $17.3 \%$ & $15.2 \%$ & $13.8 \%$ & $11.2 \%$ & $22.2 \%$ & $21.7 \%$ \\
\hline
\end{tabular}

Notes:

(1) Variables are defined in \$ millions as follows and measured for 1996:

Assets are total assets.

Municipal bonds are municipal bond holdings.

Debt is total long term debt.

Arbitrage position is the minimum of municipal bonds or debt.

Municipal bonds/assets is municipal bonds as a percentage of total assets.

Market value is the market value of the firm's equity.

Return on equity is net income divided by shareholders' equity.

(2) Firms reporting municipal bond holdings that in aggregate comprise less than $2 \%$ of total assets.

(3) Firms reporting municipal bond holdings that in aggregate comprise more than $2 \%$ of total assets. 
Table 3

Estimates of Actual and Potential Arbitrage Profits For Firms Engaging in Municipal Bond Tax Arbitrage (1)

Panel A1: Sample of 75 firms with both municipal bonds and outstanding debt (2)

\begin{tabular}{crrr} 
& \multicolumn{1}{l}{$\begin{array}{l}\text { No } \\
\text { tracing }(3)\end{array}$} & $\begin{array}{l}\text { Indirect tracing with } \\
\text { 2\% safe harbor }(4)\end{array}$ & $\begin{array}{l}\text { Direct } \\
\text { tracing }(5)\end{array}$ \\
\hline Mean & $\$ 0.343$ & $\$ 0.182$ & $(\$ 0.389)$ \\
Median & 0.039 & 0.023 & $(0.044)$
\end{tabular}

Panel A2: Relaxed definition of arbitrage for 112 firms that own municipal bonds (6)

\begin{tabular}{|c|c|c|c|}
\hline Arbitrage profits: & $\begin{array}{l}\text { No } \\
\text { tracing (3) }\end{array}$ & $\begin{array}{l}\text { Indirect tracing with } \\
2 \% \text { safe harbor (4) }\end{array}$ & $\begin{array}{l}\text { Direct } \\
\text { tracing (5) }\end{array}$ \\
\hline Mean & $\$ 0.489$ & $\$ 0.381$ & $(\$ 0.555)$ \\
\hline Median & 0.172 & 0.146 & $(0.196)$ \\
\hline
\end{tabular}

Panel B1: Sample of 20 large firms with both municipal bonds and outstanding debt (7)

\begin{tabular}{crrr} 
& \multicolumn{1}{l}{$\begin{array}{l}\text { No } \\
\text { tracing (3) }\end{array}$} & $\begin{array}{l}\text { Indirect tracing with } \\
\text { 2\% safe harbor }(4)\end{array}$ & $\begin{array}{l}\text { Direct } \\
\text { tracing }(5)\end{array}$ \\
\hline Mean & $\$ 2.952$ & $\$ 1.594$ & $(\$ 4.531)$ \\
Median & 1.372 & 0.725 & $(2.106)$
\end{tabular}

Panel B2: Relaxed definition of arbitrage for 23 large firms that own municipal bonds (8)

\begin{tabular}{crrr} 
& \multicolumn{1}{l}{$\begin{array}{l}\text { No } \\
\text { tracing }(3)\end{array}$} & $\begin{array}{l}\text { Indirect tracing with } \\
\text { 2\% safe harbor (4) }\end{array}$ & $\begin{array}{l}\text { Direct } \\
\text { tracing (5) }\end{array}$ \\
\hline Mean & $\$ 7.865$ & $\$ 6.685$ & $(\$ 12.071)$ \\
Median & 3.065 & 2.095 & $(4.704)$
\end{tabular}

Notes:

(1) All amounts are in \$ millions.

(2) This is a sample of firms from 1996 that both hold municipal bonds and have outstanding debt.

(3) The arbitrage profit under no interest disallowance is $\pi=\delta\left[R_{m}-R_{c}(1-t)\right]$

(4) The arbitrage profit with interest disallowance according to indirect tracing is $\pi_{\text {ind }}=\delta\left[R_{m}\right.$ $\left.R_{c}(1-t)\right]-\left[M / A_{b}\right] L R_{c} t$, where $M$ is the amount of municipal bonds the firm owns, $A_{b}$ is the firm's assets other than municipal bonds, $L$ is the firm's long term debt, and the otl variables are as defined previously.

(5) The arbitrage profit with direct tracing is $\pi_{\text {dir }}=\delta\left(R_{m}-R_{c}\right)$.

(6) This is a sample of firms from 1996 that hold municipal bonds. In this relaxed definition of arbitrage there is no requirement that the firm also have outstanding debt.

(7) This is a sample of large firms (assets over \$ 5 billion) from 1999 that hold municipal bonds and also have outstanding debt.

(8) This is a sample of large firms (assets over \$ 5 billion) from 1999 that hold municipal bonds. In this relaxed definition of arbitrage there is no requirement that the firm also have outstanding debt. 